CHAPTER 17

\title{
International Prosecution of Sexual and Gender-Based Crimes Perpetrated During the First World War
}

\author{
William A. Schabas
}

\begin{abstract}
Judgments of international criminal tribunals frequently refer to customary international law as a source of international crimes. The notion has been used to defeat challenges to jurisdiction based upon the nullum crimen sine lege principle. It has also been used as a source of specific offences in the application of article 3 of the Statute of the International Criminal Tribunal for the former Yugoslavia. However, the evidence of custom is often obscure and indeed mysterious. Moreover, the references are often rather tautological, seeking evidence of custom in international treaties. At the same time, some judgments also dismiss treaties as evidence of custom, arguing that they are too narrow and are only jurisdiction specific. The chapter will examine these issues with particular reference to case law of the ad hoc international criminal tribunals, the International Criminal Court and the European Court of Human Rights.
\end{abstract}

There is no doubt that ' $\mathrm{r}$ ] ape and other forms of sexual violence have long been prohibited by international humanitarian law', as a Trial Chamber of the International Criminal Court confirmed in January 2017. ${ }^{1}$ But writing in the Oxford Companion to International Criminal Justice, Katrina Gustafson said that until the establishment of the ad hoc tribunals for the former Yugoslavia and Rwanda, 'rape was largely ignored as an international crime.' ${ }^{2}$ There is certainly no question, as Wolfgang Schomburg and Ines Peterson noted, that

* William Schabas is professor of international law at Middlesex University London and professor of international criminal law and human rights at Leiden University.

1 Prosecutorv. Ntaganda (ICC-01/04-02/06), Second decision on the Defence's challenge to the jurisdiction of the Court in respect of Counts 6 and 9, 4 January 2017, para. 46. Also: Theodor Meron, 'Rape as a Crime Under International Humanitarian Law' (1993) 87 American Journal of International Law 424, at p. 424.

2 Katrina Gustafson, 'Rape' in Antonio Cassese (ed.), The Oxford Companion to International Criminal Justice (Oxford, Oxford University Press 2009), pp. 477-179. See also Theodor Meron,

(C) KONINKLIJKE BRILL NV, LEIDEN, 2018 | DOI 10.1163/9789004352063_018 
'[t]he ad hoc Tribunals are the first to have dealt extensively with crimes of sexual violence in times of armed conflict'. ${ }^{3}$

In the post-Second World War prosecutions, the term 'rape' was generally used in another context: 'the rape of Nanking', 'the rape of Czechoslovakia, ${ }^{5}$ 'the rape of Prague', ${ }^{6}$ 'the rape of the gallant Netherlands and of Belgium.' There are only isolated references in the Nuremberg proceedings to rape perpetrated by German soldiers in occupied France ${ }^{8}$ and the Soviet Union. ${ }^{9}$ Some writers have criticized a tendency to overlook the attention given to sexual violence by the International Military Tribunal for the Far East. ${ }^{10}$

The significant efforts that were made to prosecute sexual and gender-based violence perpetrated during the First World War have not been studied in any depth. At the time, violent crimes against women attracted considerable attention from the feminist movement. Notably, during the Paris Peace Conference of 1919 women's organizations intervened to insist that rape be addressed within the framework of post-war prosecutions. The post-First World War period was very much the dawn of the modern system of international criminal justice. The Hague Conventions of 1899 and 1907 did not expressly provide for individual criminal liability but they began a period of international lawmaking inspired, according to the famous Martens clause, by 'the principles of the law of nations, as they result from the usages established among civilized peoples, from the laws of humanity, and the dictates of the public conscience'.

'Rape as a Crime under International Humanitarian Law' (1993) 87 American Journal of International Law 424, at pp. 425-426.

3 Wolfgang Schomburg and Ines Peterson, 'Genuine Consent to Sexual Violence under International Criminal Law’ (2007) 101 American Journal of International Law 121, at p. 122.

$4 \quad$ United States et al. v. Araki et al., Judgment of the International Military Tribunal for the Far East, 4 November 1948, paras. 49,240, 49,605-49,612.

5 'Eleventh Day, Monday, 3 December 1945, Morning Session', (1947) 3 IMT 35; 'Thirteenth Day, Wednesday, 5 December 1945, Morning Session', (1947) 3 Iмт 173; 'One Hundred and Eighty-eighth Day. Saturday, 27 July 1946, Morning Session', (1948) 19 IMT 496.

6 'Twenty-ninth Day, Tuesday, 8 January 1946, Afternoon Session', (1947) 4 IMT 566, 568.

7 'One Hundred and Eighty-seventh Day. Friday. 26 July 1946, Afternoon Session', (1948) 19 IMT 457 .

8 'Forty-third Day, Friday, 25 January 1946, Afternoon Session', (1947) 6 IMT 178; 'Forty-seventy Day, Thursday, 31 January 1946, Afternoon Session', (1947) 6 І мт 404-406.

9 'Fifty-fourth Day, Friday, 8 February 1946, Afternoon Session', (1947) 7 IMT 179; 'Fifty-ninth Day, Thursday, 14 February 1946, Afternoon Session', (1947) 7 IMT 440, 442, 455-457; 'Sixtieth Day, Friday, 15 February 1946, Morning Session', (1947) 7 IMT 467, 494.

10 David Cohen, 'Prosecuting Sexual Violence from Tokyo to the ICC' in Morten Bergsmo, Alf Butenschøn Skre and Elisabeth J. Wood (eds.), Understanding and Proving International Sex Crimes (Beijing, Torkel Opsahl Academic EPublisher 2012), pp. 13-63, at pp. 14-15. 
Article 46 of the Regulations annexed to the fourth Hague Convention of 1907 declared: 'Family honour and rights, the lives of persons, and private property, as well as religious convictions and practice, must be respected.' The Commission of Inquiry established by the Carnegie Foundation that investigated allegations of war crimes committed during the Balkan wars of 1912 and 1913 considered the crime of rape within the framework of article 46 of the Hague Regulations. 'En réalité, le viol n'étonne plus personne, et on oublie même de le considérer comme UN crime', wrote the Commission in the chapter of the report dealing with war and international law. 'Les Bulgares, sous ce rapport, sont probablement, moins coupables que les autres. Plus patriarcaux ou plus primitifs, ils conservent en pays ennemi l'esprit du terroir et sont beaucoup plus disciplinés que les autres.'11

\section{$1 \quad$ Official Reports on Atrocities in France and Belgium}

The outbreak of the First World War in August 1914 was accompanied by allegations of a range of atrocities, including sexual and gender-based violence, perpetrated by German combatants in the occupied portions of Belgium and France. These charges figured in general discussions about war crimes. The official British inquiry, whose report was published in 1915, and that is known as the Bryce Committee, concluded that 'there is evidence of offences committed against women and children by individual soldiers, or by small groups of soldiers, both in the advance through Belgium and France as in the retreat from the Marne'. Referring specifically to northeast France, the Bryce Committee spoke of 'acts of cruelty, including aggravated cases of rape, carried out under threat of death, and sometimes actually followed by murder of the victim, were committed by some of the German troops.' ${ }^{12}$ The offical French inquiry, also published in 1915 reported: 'Les attentats contres les femmes et les jeunes filles ont été d'une fréquence inouïe. Nous en avons établi un grand nombre, qui ne représente qu'une quantité infime auprès de ceux que nous aurions pu relever; mais, par UN sentiment très respectable, les victimes de ces actes odieux se refusent généralement de se révéler.'13 Referring to Belgium, the British inquiry

11 Enquête dans les Balkans, Rapport présenté aux directeurs de la dotation par les Membres de la Commission d'enquête (Paris, Centre européen de la dotation Carnegie 1914), p. 223 .

12 Report of the Committee on Alleged German Outrages (London, HMSO 1915).

13 Rapports et procès-verbaux d'enquête de la commission instituée en vue de constater les actes commis par l'ennemi en violation du droit des gens (décret du 23 septembre 1914) (Paris, Imprimerie Nationale 1915) vol I, p. 8. 
said that '[m]urder, rape, arson, and pillage began from the moment when the German army crossed the frontier.' It continued: 'Individual acts of brutality treatment of civilians, rape, plunder, and the like - were very widely committed. These are more numerous and more shocking than would be expected in warfare between civilised Powers, but they differ rather in extent than in kind from what has happened in previous though not recent wars.' ${ }^{14}$

Some of the more outrageous charges were subsequently discounted. At one point, the Bryce Committee Report referred to a massacre of 32 civilians in the Place de l'Université in Liège, adding that 'a witness states that this was followed by the rape in open day of 15 or 20 women on tables in the square itself'. ${ }^{15}$ Elsewhere in the Report, but apparently with reference to the same incident, it said: 'A witness gives a story, very circumstantial in its details, of how women were publicly raped in the market-place of the city, five young German officers assisting.'16 The Committee Report presented this allegation in a somewhat qualified way, citing the evidence of a single witness. But the mere reference to such a notorious act with such little substantiation was rather sensationalist. It seems the allegation was subsequently discredited.

With respect to the sexual and gender-based violence, the British and French reports described these as acts of individual soldiers rather than conduct that was driven by official policy. The Bryce Committee stated that 'the maltreatment of women was no part of the military scheme of the invaders, however much it may appear to have been the inevitable result of the system of terror deliberately adopted in certain regions.' ${ }^{17}$ The French report depicted the sexual and gender-based violence as 'actes individuels et spontanés de brutes déchaînés'.18 The Bryce Committee also noted that the German military authorities could be quite harsh in punishing their own soldiers for these crimes: 'One witness reports that a young girl, who was being pursued by a drunken soldier at Louvain appealed to a German officer, and that the offender was then and there shot; another describes how an officer of the 32nd Regiment of the Line was led out to execution for the violation of two young girls, but reprieved at the request or with the consent of the girls' mother.'19 Later in

\footnotetext{
14 Report of the Committee on Alleged German Outrages (London, HMSO 1915).

15 Ibid.

16 Ibid.

17 Ibid.

18 Rapports et procès-verbaux d'enquête de la commission instituée en vue de constater les actes commis par l'ennemi en violation du droit des gens (décret du 23 septembre 1914) (Paris, Imprimerie Nationale 1915) vol I, p. 8.

19 Report of the Committee on Alleged German Outrages (London, HMSO 1915).
} 
the war, the United States executed its own soldiers for the crime of rape, ${ }^{20}$ and it seems likely that this was also the case with the British and French armies.

According to historians John Horne and Alan Kramer, 'it would be improper to assume that rapes were a dominant feature of German behaviour'. ${ }^{21} \mathrm{Nev}-$ ertheless, they concluded that 'while there was no official toleration of rape by the German army, and rape thus was not part of a reprisal policy against supposed francs-tireurs, sexual menace was ubiquitous in the violence of the German invasion.' ${ }^{22}$ There is some basis for believing that many victims of rape as well as members of their families did not report the crimes. ${ }^{23}$ There was much scepticism about the validity of the reports of atrocities, particularly during the 1920 and 1930s, when it was suggested that these were exaggerations of Allied propagandists. But more recently, historians have tended to attribute more credence to the allegations and to judge those who made them, like the British Lord Bryce, as persons of integrity. ${ }^{24}$

Almost immediately, these reports of sexual and gender-based violence attracted attention from the women's movement. Late in April 1915, the International Congress of Women convened in The Hague. The delegates - more than 1,000 women - came from the parties to the conflict, including Britain, Belgium, Austria and Germany, as well as neutral powers like the United States. Although the movement behind the Congress was focussed on universal suffrage, the agenda took up much broader themes, namely bringing an end to the war and defining the new international legal order that should emerge following the conflict. Specifically, attention was devoted to 'women's sufferings in war'. According to Freya Baetens, the records of the Congress make clear that this was a reference to 'the use of mass rape both as a strategy and a crime of war under international law'. ${ }^{25}$ Resolution 2 adopted by the Congress

20 United States Army in the World War, 1917-1919 (Washington, Centre for Military History 1948) vol 15, p. 362.

21 John Horne and Alan Kramer, German Atrocities, 1914, A History of Denial (New Haven and London, Yale University Press 2001), p. 196. Also: Stéphane Audoin-Rouzeau, L'enfant de l'ennemi (1914-1918), Viol, avortement, infanticide pendant la grande guerre (Paris, Aubier 2009).

22 John Horne and Alan Kramer, German Atrocities, 1914, A History of Denial (New Haven and London, Yale University Press 2001), p. 71.

23 Ibid., pp. 197-198.

24 Ibid., pp. 232-237; Ruth Harris, "The "Child of the Barbarian”: Rape, Race and Nationalism in France during the First World War' (1993) 141 Past \& Present 170.

25 Freya Baetens, 'International Congress of Women (1915)' in Rüdiger Wolfrum (ed.), The Max Planck Encyclopedia of Public International Law (Oxford, Oxford University Press 2012) vol v, pp. 455-459, at p. $45^{6}$. 
'oppose[d] the assumption that women can be protected under the conditions of modern warfare. It protests vehemently against the odious wrongs of which women are the victims in time of war and especially against the horrible violation of women which attends all war.'

From the earliest days of the war there were trials of captured enemy combatants for various violations of the laws and customs of war. For example, on 5 October 1914, the newspaper Échos de Paris reported that two German soldiers had been sentenced to death for pillage. But as the war wore on, the parties to the conflict came to appreciate the vulnerability of their own nationals who were prisoners, and the danger of escalating reprisals should one side insist upon trying and punishing the combatants of the other side. They reached agreements whereby sentences imposed upon prisoners would not be carried out until after the war. This practice of reciprocity no doubt saved the lives of many prisoners of war. Eventually, restrictions on the punishment of prisoners of war were codified in the Geneva Conventions, but that would have to wait until 1929 and $1949 .{ }^{26}$

In October 1918, when German defeat seemed inevitable, the governments of Britain and France revived the discussions about punishment. On 1 November 1918, the British Attorney General, Sir Frederick Smith (later Lord Birkenhead), acting under the authority of the War Cabinet, appointed a Committee of Enquiry into Breaches of the Law of War. The Committee was to enquire into and report upon the fact as to 'breaches of the laws and customs of war, affecting members of the British armed forces or other British subjects, committed by the forces of the German Empire and their allies on land, on sea, and in the air during the present war'. It was also to consider issues concerning the creation of an appropriate tribunal for such offences. The British Committee of Inquiry produced its first report on 19 December 1919. It provided two lists of war crimes, the first of a general nature to be used in prosecution of enemy combatants and the second for the trial of Kaiser Wilhelm II. In both cases, the lists were intended to define the subject-matter jurisdiction of an international criminal tribunal. The two lists were not identical, although both included a category labelled 'systematic terrorism in Belgium, France and elsewhere' that

26 International Convention Relative to the Treatment of Prisoners of War, (1932-33) 118 LNTS 343, arts. 65, 66; Geneva Convention of August 12, 1949 Relative to the Treatment of Prisoners of War, arts. 100, 101. 
could well comprise sexual and gender-based violence. ${ }^{27}$ There was, however, no direct reference to rape.

The issue of sexual and gender-based violence was explicitly mentioned in a report prepared by two distinguished members of the Faculty of Law of the University of Paris, Ferdinand Larnaude and Albert Geouffre de Lapradelle. The French document listed nine categories of war crimes, among them 'deliberate violations of the honour of young girls'. The two French academics concluded that ' $\mathrm{i}$ ] $\mathrm{n}$ all of them the Emperor, during more than four years, took a supreme part, openly or tacitly, either by ordering them or abstaining from forbidding them'. ${ }^{28}$ The French prime minister, Georges Clemenceau, spoke of the report by the French professors when he addressed the first meeting of the Preliminary Peace Conference, on 18 January 1919. Clemenceau insisted on the importance of punishing 'the authors of the abominable crimes committed during the war'.

The task of preparing the prosecutions was assigned by the Bureau of the Preliminary Peace Conference to the Commission on the Responsibility of the Authors of the War and on the Enforcement of Penalties. The reports of the French experts and of the British Committee, in particular the specific offences enumerated in those documents, provided a basis for the discussions. At its second meeting, the Commission divided into three sub-commissions, the first with responsibility for establishing the facts, the second assigned to consider legal liability for the outbreak of the war, and the third to report on legal liability for violations of the laws and customs of war. The first subcommission held only perfunctory meetings, gathering materials from the Allied governments and then compiling them. In its report it provided a list of violations that included '(5.) Rape' and '(6.) Abduction of girls and women for the purpose of enforced prostitution'. ${ }^{29}$ Details of specific allegations with respect to Belgium, Greece, and Serbia were provided in annexed tables, complete with references to documentary materials. The third sub-commission

27 'First interim report' in First, Second and Third Interim Reports of the Committee of Inquiry into Breaches of the Laws of War with Appendices, 26 February 1920, TNA CAB 24/11/13, pp. $17,98$.

28 'Inquiry into the Penal Liabilities of the Emperor Wilhelm II' in Report on the Responsibility of the Authors of the War and on the Enforcement of Penalties, Minutes of the Commission, USNA F.W. 181.1201/16, pp. 39-41, pp. 4-18, at p. 5.

29 'Report of Sub-Commission I on Criminal Acts' in Report on the Responsibility of the Authors of the War and on the Enforcement of Penalties, Minutes of the Commission, USNA F.W. 181.1201/16, pp. 39-41; 'Rapport de la 1ere sous-commission' in Conférence de Paix 1919-1920, Recueil des Actes de la Conférence, Partie IV(B)(2) (Paris, Imprimerie nationale, 1922), pp. 59-66. 
also produced a list of possible crimes. It referred to 'honour of women', citing article 46 of the Hague Convention, noting that detailed information would be provided in the report of the first sub-commission. ${ }^{30}$ The information and allegations in the report of the first sub-commission were subsequently incorporated, without modification, into the final report of the Commission, produced at the end of March 1919. ${ }^{31}$

The report referred to rapes perpertrated by German troops in August 1914 in three Belgian municipalities, Louvain, Korbeek-Lo, and Nimy. For Greece, it listed multiple cases of rape of women and girls in eastern Macedonia, carried out from 1916 to 1918 and attributed to 'Bulgarian authorities'. The list also referred to a large number of Greek victims of rape in Ayvalık (Aivali) and Goumisi, Asia Minor, in 1915, attributable to Turkish officials. With respect to Serbia, the report stated that in many villages few women were spared from rape, committed by officers and policemen but also by ordinary soldiers. It said there were many cases where women were abused in the presence of their daughters and vice versa. Often, victims were beaten before the rape and subsequently mutilated. Bulgarian soldiers with venereal diseases were ordered to rape girls. A woman was 'given up to officer's dog' by Bulgarian soldiers. There was a general allegation of rape perpetrated by Austrian soldiers against Serb women. These crimes were alleged to have been committed throughout the war and in Serbia generally. The only specific allegations concerned the locality of Požarevac (Pojarevatz). ${ }^{32}$

Only Greece was listed with respect to the crime of abduction of girls and women for the purpose of enforced prostitution. The report spoke of Greek women sent to Bulgaria as prostitutes, and more than 2,000 Greek children under 14 years of age sent to Bulgaria. It also referred to numerous cases of Greek

30 'Report of Sub-Commission III on the Violation of the Laws of War', 8 March 1919, USNA F.W. 181.12302/3; 'Rapport de la zeme sous-commission' in Conférence de Paix 1919-1920, Recueil des Actes de la Conférence, Partie IV(B)(2) (Paris, Imprimerie nationale 1922), pp. 71-81, at p. 75. Also: 'Draft report of Sub-Commission III (Prepared by the Drafting Sub-Committee and submitted to the Sub-Commission, 4 March 1919', UsNA F.w. $181 / 12302 / 2$; 'Final draft prepared by the Drafting Committee, and submitted to the Sub-Commission', 8 March 1919, USNA F.w. 181/12302/3.

31 'Report presented to the Preliminary Peace Conference by the Commission on the Responsibility of the Authors of the War and on the Enforcement of Penalties' in Report on the Responsibility of the Authors of the War and on the Enforcement of Penalties, Minutes of the Commission, usNA F.w. 181.1201/16, pp. 113-176; 'Rapport de la Commission à la Conférence des Préliminaires de Paix (29 mars 1919)' in Conférence de Paix 1919-1920, Recueil des Actes de la Conférence, Partie IV(B)(2) (Paris, Imprimerie nationale 1922), pp. 162-234. 
girls and women who were abused and detained in Turkish harems, as well as Greek children who were abducted and placed in Turkish houses. Under the heading 'Greece', the report also referred to a large number of Armenian women, girls and children who were confined to harems and converted by force to Islam. ${ }^{33}$

\section{Women Petition the Peace Conference}

In February 1919, the British delegation forwarded correspondence from the Council of Scotch Electors, a suffragist organization, concerning sexual and gender-based violence perpetrated during the war to the distribution to delegates. A covering letter from the Council, addressed to the British Minister of Foreign Affairs, asked that 'you use your influence' with the Peace Conference so as to 'give the commission of violation of rights and customs of war the necessary authority to make this question of extreme importance a vital part of this work'. It was signed by Louisa Innes Lumsden, who was president of the Council, and Alexia B. Jack, its secretary. ${ }^{34}$

Louisa Lumsden, later Dame Louisa Lumsden, was a native of Aberdeen in Scotland. She had been one of the first students at Girton College in Hitchen, a college for women located about $50 \mathrm{~km}$ north of London. After graduating, she became a lecturer at the college and, somewhat later, headmistress at St Leonards School in Fife. She is credited with introducing the sport of lacrosse to girls' schools in Britain. Lumsden had seen the sport played in Montreal by Caughnawaga Indians, describing it as 'a wonderful game, beautiful and graceful. $^{35}$ In retirement, she became an active suffragist. During the First World War, she campaigned actively to recruit soldiers. ${ }^{36}$

33 Ibid. See also: 'Notes sur les auteurs responsables des massacres d'Arménie (Mémoire de la délégation arménienne), 14 mars 1919, Conférence de Paix 1919-1920, Recueil des Actes de la Conférence, Partie IV(B)(2) (Paris, Imprimerie nationale 1922), pp. 511-514.

34 Letter from Louisa Lumsden to Foreign Secretary and annexed documents, 7 February 1919, USNA F.W. 185.118/23. See also: Council of Scotch Electors, 6 March 1919, TNA FO $608 / 161$.

35 Louisa Innes Lumsden, Yellow Leaves, Memories of a Long Life (Edinburgh and London, William Blackwood and Sons 1933), p. 81.

36 Elizabeth J. Morse, 'Lumsden, Dame Louisa Innes (1840-1935)' in Oxford Dictionary of National Biography (Oxford, Oxford University Press 2004) [http://www.oxforddnb.com/ view/article/48571, accessed 26 Jan 2017]. 
The Secretariat of the Peace Conference organized the translation of the materials into French and on 4 March 1919 the documents were distributed: ${ }^{37}$

\section{ELECTORS COUNCIL (NON POLITICAL) \\ Edinburgh Group $\quad 7$ February 1919}

To the Representatives of the Allied Powers assembled in conference.

Sirs:

The Council of Scotch Electors, Society composed of men and women, have noted with profound pity the lot of women and young girls of Allied countries who have been subject of brutal treatment or who have been taken into slavery by enemy troops and would like to bring this question to the attention of the powers assembled at the Peace Conference.

We want to insist that the Governments of the Allied Nations should without delay try and hunt for and find and return to their homes men as well as the women who have been taken, deported or sold by the Germans and their Allies, and to assure the punishment of all those who are found to be connected with these atrocities.

The Council of Scotch Electors would also like to call to the attention of the conference the fact that the Greek military mission is occupying itself at present and trying to find the women and young girls who were violated and taken away by Bulgars and Turks. It would be well to include this question which is of the greatest improtance in the work of the Commission constituted by the conference to occupy itself with the "violations of the laws and customs of war" and that also this question might fall under the fifth article of the resolutions that have been adopted by the conference.

Civilized women can no longer stand that violations committed on women should be neglected under pretext of being regrettable incidents of war.

Please accept sir the expression of our deapest respect.

Signed: Louisa Innes Lumsden. President Alexia B. Jack. Secretary. ${ }^{38}$

37 Letter from Secretariat General to US delegation, 4 March 1919, USNA F.w. 185.118/23.

38 Letter from Louisa Lumsden to Foreign Secretary and annexed documents, 7 February 1919, USNA F.W. 185.118/23. 
In mid-April, the Secretariat of the Conference distributed two other submissions along similar lines, one from women in the United States of America and the other from those in France. The document from the United States was the resolution of a body named the 'Committee on the Protection of Women under International Law'. The Secretariat distributed the resolution, translated into French, noting that it had been signed by 'cinq millions de Femmes Américaines, désireuses de protester contre les outrages dont les troupes des Puissances ennemies se sont rendues coupables à l'égard des Femmes des pays alliés.' ${ }^{39}$ The claim that it was signed by 5 million American women must surely be inaccurate. At the time, the population of the United States was about 100 million. That would mean that one in every ten female Americans signed the petition, which seems unlikely. The text read as follows:

\section{RESOLUTION}

WHEREAS there is overwhelming evidence that in the present war the armies of the Central European Powers and of their Allies have been permitted and encouraged to commit and, officers and men en masse, have actually committed every form of sexual offence against the women of every country they have entered.

WHEREAS such offences are crimes as well under the laws of war as under the laws of peace, as well under the common law of nations as under the municipal law of every nation which is even superficially civilized; and under the Hague Conventions.

WHEREAS such crimes, besides their monstrous insult to the dignity of womenhood strike at the heart of society, the home. And the deliverate, wholesale, authorized commission of them by the Germans and their Allies confronts Society, accordingly, with the alternatives EITHER, acquiescing in its own destruction to allow the violation, the mutilation, the enslavement and compulsory prostitution of womena nd girls to become established by foerce of precedent as a permitted custom under the laws of war; Or unmistakbly to destroy that precedent;

AND INASMUCH AS more than a million French women have unitedly appealed to the women of all countries to join them in denouncing this infamous and sinister attack on the common life of humanity through its womankind;

39 Letter from Secretariat of Peace Conference to US delegation, 19 April 1919, USNA F.W. $185.118 / 62$. 
THEREFORE we, women of the United States, hereby

1. Associate ourselves with the women of France in their Protest and Appeal, which is annexed hereto.

2. Demand that any officers, solders or civilian of the Central Powers of their Allies who have been Guilty of any sexual offence against a woman or girl of France or her allies, in the course of the present war, be punished if possible, especially in flagrant and notable cases, and that measures be taken by the nations in Conference, that in any further war, the Commission of these dangerous and degenerate villianies be absolutely forbidden and denounced, and adequate pealties with proper methods of enforcing them be carefully provided and promulgated.

3. Declare our own deliberate feeling, judment and position to be that all women so injured by a despicable enemy ought to be treated and regarded, not as shamed, but as wounded in war. And we implore our Allies to confer that status on them, both officially and in the public mind.

FURTHERMORE, we directuly our Committee in charge to deliver these RESOLUTIONS duly authenticated, to each of the Government, (including our own Government) allied against any or all of the said Central Powers and their Allies in the present war, and to each of the Societies associated in the Appeal of the French Women, and to arrange so far as possible, for their publication in every allied country. ${ }^{40}$

To the same effect, a French organization, the Alliance Universitaire Française, presented a petition to the Peace Conference. According to the Alliance, the petition had been signed by 15,000 people, a number that seems rather more plausible than the figure of 5 million claimed for the American petition. The text of the petition was translated into English and circulated to delegates at the Peace Conference on 22 April 1919:

Petition to members of the Peace Conference

In contravention of the most elemental laws of humanity thousands of women, young girls, and even children in the north of France and in Belgium, of all social conditions, have been systematically dragged from their families, contaminated by order, submitted to worse promiscuousness, treated like slaves.

$40 \quad$ Ibid. The numerous typographical and grammatical errors have not been identified using [sic]. 
Our hearts broken and bleeding, we the women of France ask of the Allied Nations, come before the Peace Conference to ask for justice in the name of our martyred sisters.

To prevent forever the recurrence of such atrocities, we ask that those who have ordered them and those who have carried them out be condemned like criminals under common law.

We count on your firmness to ensure that Germany and her Allies, who have armed the hands of these executioners be placed under the ban of humanity. 41

Accounts by historians about the women's movement at the time do not mention this campaign to promote prosecutions of rapes committed by German combatants. Indeed, the author has found no references whatsoever to the documents on sexual and gender-based violence that were circulated at the Paris Peace Conference in either the writings of historians or those of legal academics interested in the subject of post-war prosecutions. The central issue in the feminist movement at this time was obtaining the right to vote, although that does not mean that it was indifferent to a broad range of matters falling generally under the rubric of women's equality. Women's organisations had been sharply divided in their attitude towards the war, with a large number campaigning for peace while many of their sisters, like Louisa Lumsden, fell into step with wartime patriotism and nationalism. ${ }^{42}$ It may be that those campaigning for prosecution of Germans for war crimes, including rape and other sexual and gender-based violence, were linked to the more militarist part of the movement. Women who had been associated with pacifism would also, following the war, have tended to align themselves with those who were critical of the Treaty of Versailles and other measures directed at Germany and Austria. This explains why the International Congress of Women, meeting in Zurich in May 1919, did not adopt any resolutions about the post-war prosecutions. Indeed, there is no record of the issue even being discussed. ${ }^{43}$

41 Letter from Secretariat of Peace Conference to US delegation, 22 April 1919, USNA F.w. 185.118/62; Letter from Secretariat of Peace Conference to British delegation, 22 April 1919, TNA FO 608/247/12.

42 Alison S. Fell and Ingrid Sharp, 'Introduction: The Women's Movement and the First World War' in Alison S. Fell and Ingrid Sharp (eds.), The Women's Movement in Wartime, International Perspectives, 1914-19 (Basingstoke and New York, Palgrave 2007), pp. 1-17.

43 Anne Wiltsher, Most Dangerous Women (London, Boston and Henley, Pandora 1985), pp. 200-211; Gertrude Bussey and Margaret Tims, Pioneers for Peace, Women's International League for Peace and Freedom (London, George Allen \& Unwin 1965), pp. 24-33; Erika Kuhlman, 'The "Women's International League for Peace and Freedom" and Reconciliation after the Great War' in Alison S. Fell and Ingrid Sharp (eds.), The Women's Movement 
The International Congress of Women was the successor of the 1915 Congress in The Hague where violence against women had been protested, but essentially from a pacifist perspective.

\section{$4 \quad$ Plans for Prosecution of Sexual and Gender-Based Violence}

The Commission on Responsibilities concluded its work at the end of March 1919. The members of the Commission would by then have received the statement from the Council of Scotch Electors but they would yet not have obtained the petitions from the American and French organizations. There is no reference in the debates of the Commission to the petition from the Scottish women. For that matter, the minutes of the Commission and its sub-commissions do not indicate any discussion whatsoever about the issue of rape and enforced prostitution.

The recommendations of the Commission on Responsibilities were only partly followed by the Council of Four when it prepared the text of the Treaty of Versailles, in April and early May 1919. Woodrow Wilson and Emanuele Orlando would probably have been happy enough to drop the matter of prosecution altogether. But faced with the insistence of Georges Clemenceau and David Lloyd George they agreed to incorporate provisions in the text of the Treaty of Versailles. The clauses themselves, eventually numbered articles 227 to 230 of the Treaty, were crafted by Wilson personally in an effort at consensus and then approved by the three other leaders as well as the Japanese representative. ${ }^{44}$

After the Treaty was signed, on 28 June 1919, the Allies hastily prepared lists of prisoners to be surrendered by Germany in accordance with article 228 . Following protracted negotiations, a compromise was reached whereby the trials were to take place before German courts in Leipzig, based upon a limited selection from the original list of wanted men. Only 45 candidates for prosecution were identified. Most of these concerned the actual conduct of hostilities on land and at sea, as well as abuses directed at prisoners of war. ${ }^{45} \mathrm{~A}$ few dealt with atrocities against the civilian population. However, none of the charges referred to sexual and gender-based violence.

in Wartime, International Perspectives, 1914-19 (Basingstoke and New York, Palgrave 2007), pp. 227-243. 
Pursuant to article 227 of the Treaty, the former Kaiser Wilhelm II was arraigned for 'a supreme offence against international morality and the sanctity of treaties'. The unusual wording was proposed by Wilson based on language used in a letter from his Secretary of State, Robert Lansing. Lansing was himself quite vehemently opposed to prosecution of the Kaiser and almost certainly had not intended for his words to be used in defining a crime under international law. ${ }^{46}$ Be that as it may, the four leaders agreed on the formulation. Today, the offence defined in article 227 is generally understood as being directed to the illegality of the war, the jus ad bellum, rather than to the violations of the laws and customs of war commited in the conduct of hostilities and in occupied territories. But it does not seem that this was the view adopted by the British when they made their initial preparations for the trial of the Kaiser.

In July 1919, R.W. Woods was assigned by the Solicitor General to prepare the case against the Kaiser. He relied very largely on published sources, including the Bryce Committee report and similar materials prepared by other countries. His detailed memorandum, consisting of more than 200 pages, devoted considerable attention to the violations of the laws and customs of war. Woods wrote: 'Of the violation of women, there is unfortunately a surfeit of evidence In all the reports, instances will be found of loathsome debauchery on the part of Officers and men of the German Army. It may be obserbed that it was by no means unknown for the women to be dragged before a Belgian Priest and violated in his presence. ${ }^{47}$ Woods concluded that the Kaiser might be held responsible in a general sense for German atrocities, as he either condoned them or ignored them, but he made no specific reference in his report to liability of the former emperor the sexual and gender-based violence. ${ }^{48}$

The Treaty of Versailles entered into force on 10 January 1920. Immediately, a demand was made by France, Italy and the United Kingdom for his surrender, but the Netherlands refused extradition. ${ }^{49}$ The Dutch government reacted to Allied pressure by agreeing to confine the Kaiser to his new residence in Doorn, near Utrecht, and to prevent him from engaging in political activity. By this point, the thirst for justice had decline considerably from its paroxysm in late 1918. The principal concern of the victorious powers was royalist intrigue

46 Lansing to Wilson, 8 April 1919, F.W.181/1202/7.

47 The Arraignment of William II of Hohenzollern, Memorandum on the Responsibility of William II of Hohenzollern for Acts Committed in Breach of the Laws of War, TNA TS 26/1, p. 201.

48 Ibid., pp. 211-213.

49 'Note to the Queen of Holland demanding the Delivery of the Kaiser for Trial' in Rohan Butler and J.P.T. Bury, Documents on British Foreign Policy 1919-1939 (1st series, London, His Majesty's Stationery Office 1958) vol II, pp. 912-913. 
in an unstable Germany. After a few more belated requests for extradition, the Allies dropped the matter. ${ }^{50}$

\section{$5 \quad$ By Way of Conclusion}

The project of international criminal justice as we know it today really began with the efforts to prosecute combatants and officials of the countries that were defeated during the First World War, principally Germany. The sexual and gender-based violence perpetrated during the conflict did not result in any trials or convictions, at least to the extent that this was mandated by international law. But much the same can be said of the other violations of the laws and customs of war, with the exception of the handful of cases dealt with at Leipzig. Rape and enforced prostitution were addressed by the Commission on Responsibilities as part of its overall examination of violations. The codification adopted by the Commission that includes these two crimes was influential when international justice was revived during the Second World War. For example, René Cassin, the vice-president of the London International Assembly, reproduced the Commission's list of crimes in a report on Nazi war crimes. ${ }^{51}$ The list was also considered by the United Nations War Crimes Commission in 1944 as it examined the specific acts to be included in the concept of laws and customs of war. ${ }^{52}$

Of particular interest is the engagement of women's organizations at the time with the issue of prosecution. The debate within the feminist movement may have been influenced by the position taken towards the war itself, with those on the pacifist side of the fence being less enthusiastic not because they were indifferent to violence against women but out of concern that a focus on prosecution might obstruct efforts at reconciliation.

$5^{\circ}$ 'Reply to the Dutch Government, as approved by the Conference of Ambassadors and Foreign Ministers on March 24, 1920' in Rohan Butler and J.P.T. Bury, Documents on British Foreign Policy 1919-1939 (1st series, London, His Majesty's Stationery Office 1958) vol viI, pp. 616-617.

$5^{1}$ René Cassin, 'Note of violations of the laws and customs of war perpetrated by the Germans since September 1939' in London International Assembly, Reports on Punishment of War Criminals (1943), pp. 42-55, at p. 50. Also: M. De Baer, 'Scope and Meaning of the concept of war crimes' in London International Assembly, Reports on Punishment of War Criminals (1943), pp. 156-162, at p. 159 . UNwCC II/11; Article I of Draft Convention on the Trial and Punishment of War Criminals, 12 June 1944, UNWCC II/17. 